\title{
EXPLORING THE IMPACT OF ETHNOCENTRISM ON COUNTRY AND BRAND IMAGE: THE CASE OF PEUGEOT
}

\author{
DOI: 10.17261/Pressacademia.2021.1392 \\ RJBM- V.8-ISS.1-2021(4)-p.37-50
}

\section{Bayram Z. Erdogan ${ }^{1}$, Bulent Aydin², Deniz Kirmizi}

${ }^{1}$ Anadolu University, Department of Marketing, Eskisehir, Turkey. bzerdogan@anadolu.edu.tr, ORCID: 0000-0002-2147-7356

${ }^{2}$ Batman University, Department of Tourism, College of Tourism and Hotel Management, Batman, Turkey. baydin1986@gmail.com , ORCID: 0000-0002-5449-4611

${ }^{3}$ Anadolu University, Department of International Business, Eskisehir, Turkey. seared88@hotmail.com, ORCID: 0000-0003-0911-3880.

\begin{tabular}{l}
\hline Date Received: January 16, $2021 \quad$ Date Accepted: March 27, $2021 \quad$ open Oaccess \\
\hline To cite this document \\
Erdogan, B.Z., Aydin, B., Kirmizi, D. (2021). Exploring the impact of ethnocentrism on country and brand image: the case of Peugeot. Research \\
Journal of Business and Management (RJBM), V.8(1), p.37-50. \\
Permanent link to this document: $\frac{\text { http://doi.org/10.17261/Pressacademia.2021.1392 }}{\text { Copyright: Published by PressAcademia and limited licensed re-use rights only. }}$ \\
\hline
\end{tabular}

\section{ABSTRACT}

Purpose - It is important to determine the ethnocentric tendencies of Turkish consumers and to reveal the effects of these tendencies on a foreign country and its brand. The aim of this paper is to explore the impact of ethnocentric tendencies of individuals trained in Turkish culture affect the image of a foreign country and its products. For this purpose, research has been carried out on the Peugeot brand of France origin, which is one of the best-selling automobile brands in Turkey.

Methodology - Data was collected from 400 people by face to face in the city center of Eskisehir. As the research was conducted only in one city, it does not cover all Turkish consumers. In terms of measurement, country image scale, country product image scale and the CETSCALE were used. In this study Structural Equation Modeling (SEM), t test and ANOVA were performed.

Findings- The ethnocentric tendency of Turkish consumers and other relationships were tested with the hypotheses $\mathrm{H} 1, \mathrm{H} 2$, $\mathrm{H} 3 \mathrm{a}, \mathrm{H} 3 \mathrm{~b}, \mathrm{H} 4$, $\mathrm{H} 5 \mathrm{a}$, $\mathrm{H} 5 \mathrm{~b}, \mathrm{H} 6 \mathrm{a}$ and $\mathrm{H} 6 \mathrm{~b}$. According to the findings, $\mathrm{H} 1, \mathrm{H} 4, \mathrm{H} 5 \mathrm{~b}, \mathrm{H} 6 \mathrm{a}, \mathrm{H} 6 \mathrm{~b}$ were supported but, $\mathrm{H} 2, \mathrm{H} 3 \mathrm{a}, \mathrm{H} 3 \mathrm{~b}$ and $\mathrm{H} 5 \mathrm{a}$ were not supported.

Conclusion- The ethnocentric tendency of customers affects only the image of the country of origin, in this case, it negatively affects the image of France. However, it doesn't affect the general image of French products and brand image statistically. Also, general image of country products and France's image positively and significantly affects brand image.

Keywords: Country image, product image, brand image, ethnocentrism, Peugeot, France. JEL Codes: M30, M31

\section{INTRODUCTION}

With the increase of international trade, competition between domestic and foreign products in the country's markets has increased. Initially it has been seen that in the flow of trade the consumers were affected by the country image and preferred the goods of developed countries (Schooler, 1965; Nagashima, 1970; Wang and Lamb, 1983; Han, 1990). In this aspect, the research on the preference of imported products have focused on the image of the country of origin and the product image. As a result of these studies, it has been determined that country of origin has a strong effect on the product image and changes the quality perception of the product (Roth and Diamantopoulos, 2009; Ahmed et al. 2002). Although the developed countries have a positive image, it is known that they cannot reflect this positive image to all of their products. Countries are more likely to have a positive effect on the products in the categories they are gifted; but in the categories in which, they are not gifted even the developed countries have not been able to influence their products' images positively (Rothand and Romeo, 1992; Koubaa, 2008). Therefore, the image of the country's product category has begun to come to the forefront much more than the level of the development of the country. In this aspect, an undeveloped country can have a very good image in a specific product category. While the researches are concentrating on country and product image in the undeveloped and developing countries, the concept of ethnocentrism has begun to appear in developed countries. Because even in the developed countries such as USA, the consumers 
prefer imported products but it has also been reported that the number of customers who have an ethnocentric tendency have also been increased (Shimp and Sharma, 1987). With the entrance of Japanese automobiles in the market of America's advanced automobile industry, this situation has lost its effectiveness and damaged the American automobile industry (Wang and Lamb, 1983).

Therefore, since the developed countries have their alternatives to imported products, the main variable that affects the consumers' preference has been largely ethnocentrism than the image. In the places where ethnocentrism is dominant, the image of the trading country and the images of its products remain on the second place. Because the customers who have ethnocentric tendency find it more appropriate to choose their own products due to various concerns (economic reasons, job loss, etc.) (Shimp and Sharma, 1987).

The case of ethnocentric tendency is also valid for developing countries. In these countries, the customers mainly prefer their own products (Erdogan and Uzkurt, 2010; Han and Wang, 2014), domestic products against foreign products; and if there is no alternative domestic product, they prefer the products of the countries which are close to their own culture. (Watson and Wright, 2000). The customers are taking a positive attitude towards domestic products which are alternative to foreign products or for the products from countries with which they are culturally close, they have taken a negative attitude towards foreign products (Watson and Wright, 2000). The poor quality of domestic products versus foreign products can sometimes change this attitude in the opposite direction (Wang and Chen, 2004). However, products that fall into heavy industry category like automobiles seem far away for developing countries. Therefore developing countries have to choose brands from the developed countries even though they are not culturally close to them. From this point view, it's important to determine how ethnocentric tendency in developing countries influences the country of origin, product and brand image for the products such as automobiles that don't have a domestic alternative.

This research has been directed towards developing countries which is one of the limited areas in the literature. In this context, Turkey which attempts to produce domestic automobile has been selected as a research country. Thus in case of Turkey's domestic automobile production, the other imported automobile market how will be affected by ethnocentric tendencies has also emerged. The research provides significant contributions both literature and practitioners.

With this research, it is aimed to determine the effect of the ethnocentric tendencies of consumers towards one of the most preferred foreign automobile brands in Turkey as a developing country. In this context, the Peugeot brand, one of the most preferred automobile brands, has been selected to determine the effect of ethnocentrism on the brand image, country of origin and general product image of the country of origin.

The paper is structured as follows. Firstly, a review of literature on Ethnocentrism, Product Country Image and Brand Image will be conducted, then Data and Methodology, Findings, Conclusion and Managerial Implications will be presented.

\section{LITERATURE REVIEW}

\subsection{Ethnocentrism}

The concept of ethnocentrism is based on the fact that it sees its own groups in the center of the universe, interprets other social units in terms of their groups (Erdoğan and Uzkurt, 2010; Özçelik and Torlak, 2011) and defined as an attitude that evaluates other cultures according to their own cultural standards (Thomas and Hill, 1999). From a functional point of view, ethnocentrism allows the person to understand the acceptance or inadmissibility of purchasing behavior in the group in which the person is present (Shimp and Sharma, 1987). From the ethnocentric point of view, the purchase of imported goods is wrong because according to them, this causes damage to the local economy, causes job losses, contradicts patriotism and constitutes a sign of disrespect for the excessively ethnocentric consumers (Shimp and Sharma, 1987).

There are several reasons why consumers have ethnocentric considerations. These include: family, opinion leaders, friends circle and media (Shimp, 1984); the past events of the country: wars, trade borders, economical-political events (Herche, 1994) and sense of losing business due to foreign products (Usunier, 1996, pp. 285). Ethnocentric tendencies have a strong relationship with the demographic characteristics of consumers (Erdoğan and Uzkurt, 2010). Watson and Wright (2000) stated that women, old people, the people who have low education levels and low income levels are more ethnocentric than other individuals. Also, nondemographic factors such as belief, person's social environment and intentions affect the customer's ethnocentric tendencies (Martinez et al., 2000).

In general, consumers tend to prefer products produced in their own countries. In his study, Reierson (1966) asked American students about their thoughts on Swiss, German, Italian, American, French, Japanese and British products and the result of his 
research showed that American students prefer American products in comparison to the other countries' products. However, it is known that this situation differs for consumers in developed and developing countries. For example, while studies of American, French, and Scandinavian consumers have shown that consumers prefer their products instead of other countries' products. On the other hand it has emerged that Iranian consumers have positively evaluated and preferred products when there is a foreign label involved (Usunier, 1996). It's stated that there is a similar situation for customers in Puerto Rico (Bilkey and Nes, 1982). However, regardless of how advanced the countries are, imported products can also be preferred depending on the product type. Losing effectiveness and the damage to the American automobile industy by the Japanese automobiles entries to America's advanced automobile industy may be an example of this situation (Wang and Lamb, 1983). It is also known that in countries where there are no local alternatives, consumers tend to prefer foreign products (Morello, 1983).

Ethnocentric tendencies can also affect consumers' perceptions of a foreign country and its products (Sharma, Shimp and Shin, 1995; Watson and Wright, 2000; Kaynak and Kara, 2002; Moon and Jain, 2002; Erdogan and Uzkurt, 2010; Fakharmanesh and Miyandehi, 2012). Especially in countries where there are no domestic alternatives, the ethnocentric tendency has been identified as an opportunity for countries and products with cultural similarities (Watson and Wright, 2000). According to Erdogan and Uzkurt (2010), consumers with a high ethnocentric tendency perceive foreign products negatively while perceiving domestic products positively. But if the people are open to different cultures, this situation reduces the ethnocentric tendency (Sharma, Shimp and Shin, 1995). The quality issue related to the product also reduces the effect of ethnocentrism. Especially the quality of domestic products is also very influential in the preference over foreign products. When domestic products are perceived as of poor quality, consumers may prefer imported products (Elliott and Cameron, 1994). The quality perception of the consumers may vary according to the level of need, product and country of origin (Huddleston and Stoel, 2001).

There are many variables affect consumer preferences and attitudes in international markets and it is known that image of country, product and brand are the most important of those. But ethnocentrism reduces the positive effects of these variables. Ethnocentric tendencies can be more effective than country image, product and brand image. People believe that ethnocentric considerations may refuse to use imported products regardless of the origin of the products and the brand image (Herche, 1994). This situation may occur for consumers both in developed and developing countries. While intensive researches conducted on ethnocentric tendencies of consumers in developed countries but others countries' consumers neglected. Thus there are some gaps in the literature about developing countries. In this respect, this study aimed to determine the effects of ethnocentric tendencies by focusing on the consumers of a developing country. Thus Turkey as a research country and an auto brand Peugeot which is originally French was selected for the study. The following hypotheses determined how the brand, country of origin and general product image are affected by ethnocentric tendencies.

Therefore, the following hypotheses have been developed to determine how Peugeot, a French brand, imported in Turkey, is influenced by ethnocentric tendencies:

H1: Ethnocentrism negatively affects France's image,

H2: Ethnocentrism negatively affects the general image of French products,

H3: Ethnocentrism negatively affects the Peugeot brand image.

\subsection{Product Country Image (PCI)}

It is known that the product and country image are used by consumers and affect consumers in various forms. Numerous studies have been carried out in this area in past and still researchers are deeply interested in exploring the related area more. According to studies carried out by (Nagashima, 1970; Han, 1990; Lee and Tse, 1993; Parameswaran and Pisharodi, 1994; Essoussi and Merunka, 2007; Maher and Carter, 2011) its stated that the consumers affect the product image (Schooler, 1965; Nagashima, 1970; Roth and Romeo, 1992; Parameswaran and Pisharodi, 1994; Dinnie, 2003; Felzensztein and Dinnie, 2005; Lin and Chen, 2006; Roth and Diamantopoulos, 2009) and brand image (Lee and Tse, 1993; Lee and Ganesh, 1999; Essoussi and Merunka, 2007; Koubaa, 2008). Therefore, products and brands can affect the country image positively or negatively as the image of the country affects the product image and brand image.

The country image can be considered by consumers before any product (or brand) is preferred (Huddleston et al., 2001; Baker and Ballington, 2002; Hinner, 2010). It's stated that the consumers use the country image either as a halo effect or summary construct (Bruning, 1997). In the context of the cues, consumers use the country image as a single cue or multiple cues in product evaluations. In the case of single cue, the only information source that consumers have in product evaluations is where the product is produced. In the researches in which multiple cues are used, other information is shared with consumers along with country of 
origin (Bilkey nd Nes, 1982). Hence, it's stated that the country of origin effect is greater in the single cue research than multiple cues research (Bilkey and Nes, 1982; Peterson and Jolibert, 1995). However, adding other cues such as brand name, demographic items, and familiarity with the product, decrease the country of origin effect (Maronick, 1995). The country of origin effect used as a halo effect and summary construct (Han, 1989; Han, 1990; Martin and Eroglu, 1993; Al-Sulaiti and Baker, 1998; Lampert and Jaffe, 1998; Ahmed et al. 2002; Insch et al., 2015). According to Han (1990), consumers use the country image as a clue when they are not familiar with country's products as a quality sign and they generalize this knowledge to other products of the country when they know the country and its products. In other words, as a result of consumer experience the halo effect on the goods and services linked to the country become a summary construct (Nebenzahl et al., 1997). According to Lampert et al. (1998), the consistency of product images of a country and brand images similarity results in image crystallization leading to summary effect. Thus, there is a common image of the products produced in the country and the country image is perceived in the same way (Lampert, et al., 1998). Also, when the summarization effect is used, sensitivity to the country of origin is also evident (Johansson, 1989). Initially country image was measured by the product image on product country image researches but later it's stated that two concepts are different from each other (Papadopoulos and Heslop, 1993; Martin and Eroglu, 1993). When the first studies which were evaluating the product examined, the country image was reflected by its products and therefore, the quality of the products is seen as a country image (Schooler, 1965; Reierson, 1966; Nagashima, 1970; Nagashima, 1977). Thus, the products of economically developed countries are perceived as better quality products than the products of the developing countries Huddleston et al., 2001). However later on, the country image was started to be evaluated depending on the product groups regardless of how advanced the country economically was (Wang and Lamb, 1983; Roth and Romeo, 1992; Lampert and Jaffe, 1998; Koubaa, 2008). In addition, acculturation level and the country of origin also positively affects the evaluation of the country and its products (Suh, Hur ve Davis, 2016). Thus, considering the above discussions it is understood that the image of the country can also affect the product image positively or negatively. As a result, the following hypothesis determined to test how France affects products of origin.

H4. The France image affects the general image of French Products positively and significantly.

\subsection{Brand Image}

A brand consists of name, designation, symbol or design that is designed to distinguish the seller or seller's group. (Aaker, 1991; Kotler, 1991). The brand identifies and represents a specific product. But it contains a lot more meaning than a name. It reflects what consumers think and feel about the product. The image is defined as the sum of the beliefs, attitudes and impressions of individuals or groups about certain objects (Barich and Kotler, 1991). The image is defined as the sum of the beliefs, attitudes and impressions of individuals or groups about certain objects (Kapferer, 2008, s. 174). According to Erdoğan et al. (2015), the image of an object develops through the set of impressions that individuals have obtained directly or indirectly as a result of encountering that object.

The brand image is the perception that the consumer has in his mind as a result of various communications by a set of associations organized in a meaningful way. The brand image, which is settled in the consumer's mind, affects consumers' purchasing intentions, satisfaction degree of purchased product and also the degree of certainty of purchasing decisions (Akkaya, 1999, s. 108). Dobni and Zinkhan (1990) stated that, the concept of "brand image" which was first introduced by Levy in 1955 has changed in 35 years and by studying 28 studies, they have reached the following conclusions about the brand image.

- Brand image is the concept of a brand that is held by the consumers.

- Brand image is largely a subjective and perceptual phenomenon that is formed through consumer interpretation, whether reasoned or emotional.

- Brand image is not inherent in the technical, functional or physical concerns of the product. Rather it is affected and molded by marketing activities, by context variables, and by the characteristics of the perceiver.

- Where the brand image is concerned, the perception of reality is more important than the reality itself.

Researches shows that country and general product image have effects on brand image. According to Koubaa (2008) investigating the effects of country of origin knowledge on brand perception and brand image structure as well as brand origin having a strong influence on the brand perception. Moreover country image also has a strong influence on brand image. Similarly, Lee and Ganesh (1999) point out the relationship between country, product and brand image. Brand and country of origin congruity also have an important role on consumers' brand perception (Eng, Ozdemir and Michelson, 2016). In addition, economic development of the consumers' country and positive biases of consumers also have favourable effects on brand image (Kinra, 2006). Therefore, the fact that the country of consumption is a developing country and consumers have a positive attitude towards the brands of the developed countries provides an important advantage for brands. Thus, according to Ahmed et al. (2002), a strong country image 
can compensate for a weak brand image. Furthermore, having a strong image in the product categories positively influence the attitude toward the brand (Diamantopoulos vd., 2011). Hence, the following hypotheses have been determined to test the relationship between product, country and brand in a different population.

H5. The France image affects the Peugeot brand image positively and significantly.

H6. The general image of French products affects the Peugeot brand image positively and significantly

\section{DATA AND METHODOLOGY}

\subsection{Sample and Data Collection}

The research data was collected from 400 people in the city center of Eskişehir which is one of the cosmopolitan cities in Turkey through questionnaires. Eskişehir is located in the middle of Turkey and is one of the most diverse cities regarding demographic, socio-economic and cultural characteristics. Convenience sampling was used in this research and the data was collected by the researchers face to face with 378 employees and 22 non-working people living in this city. Participants selected from volunteers and car ownership experience was not an obligation. Thus, both car ownership and potential car buyers included in the study. The questionnaire to collect the data was applied in two ways. To measure whether participants were affected by the order effect of the survey sections, the questionnaires were divided into two groups of 200 pieces. The sequence of questions in the first format of questionnaire was; demographic characteristics, Peugeot brand image, France image and the general image of French products and ethnocentrism. The sequence of questions in the second format of questionnaire was; Demographic characteristics, ethnocentrism Peugeot brand image, France image and general image of French products.

\subsection{Measures}

The survey used in the research consists of 4 parts. These parts are: statements containing demographic characteristic, brand image scale to measure the perceptions of consumers (Koubaa, 2008), country image scale and country product image scale (Lee and Ganesh, 1999) and the CETSCALE scale, which has been used in a wide variety of sources in the literature (Shimp and Sharma, 1987; Good and Huddleston, 1995; Erdoğan and Uzkurt, 2010; Asil and Kaya, 2013) to measure consumer attitudes towards nationalistic values and has proven its reliability. CETSCALE was previously translated into Turkish by Erdoğan and Uzkurt (2010) and Asil and Kaya (2013), so no translation was needed. However, other scales were translated into Turkish by a group of experts in English and Turkish languages. All scales which took part of this study were used before and have proven their validity and reliability.

The research investigated the effects of ethnocentric tendencies on the Peugeot brand, one of the best-selling automobile brands in Turkey, and the country of origin, France and General image of French Products. For the evaluation of attitudes of consumers 5 Likert- type measurement "I certainly do not agree-I strongly agree" was used.

The model for the study was designed as follows.

Figure 1. Research Design

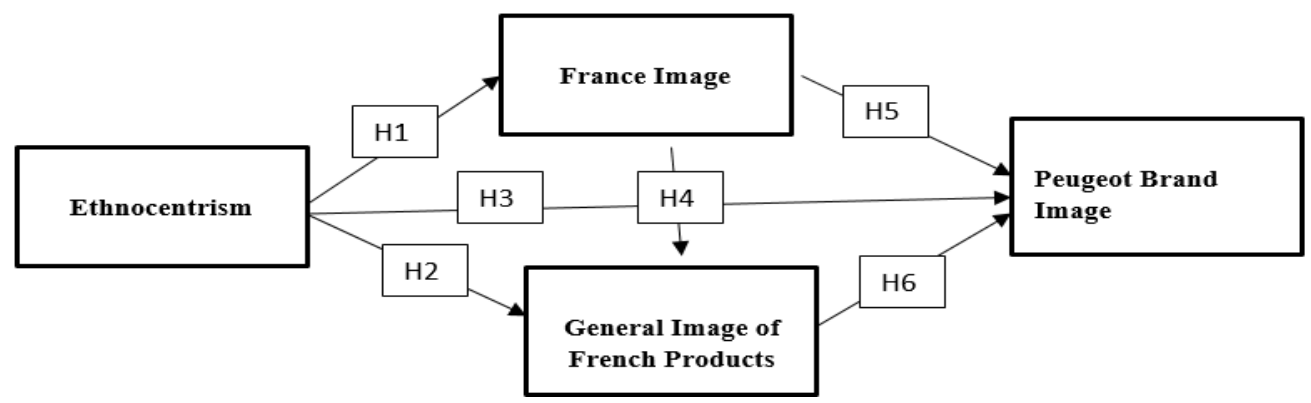

\subsection{Analysis}

In the research, for construct validity, Exploratory Factor Analysis and Confirmatory Factor Analysis were used with the help of SPSS and AMOS. Descriptive statistics (frequency, mean etc.) were calculated and to test the hypothese Structural Equation Modeling was used. It is known that SEM is frequently applied to the relationship between endogenous and exogenous variables in social sciences. For normality test the values of "Skewness" and "Kurtosis" were checked. For normality values between +1.5 
and -1.5 are accepted as normal (Tabachnick and Fidell, 2011), values between +2 and -2 are also accepted (Darren and Mallery, 2003).

\section{FINDINGS}

\subsection{Profile of the Respondents}

The descriptive statistics of the participants are presented in Table 1 below. It appears that the vast majority of participants consisted of employees who have at least bachelor's degree and were identified as white-collar employees. In the research, the participants were questioned about the brands of the automobiles they own with the help of open-ended questions. According to the answers given, the automobile brands and the automobile numbers are given in Table 2 .

Table 1: Sample Characteristics

\begin{tabular}{|c|c|c|c|}
\hline Characteristics & & Frequency & Percentage \\
\hline \multicolumn{4}{|l|}{ Gender } \\
\hline & Male & 187 & 46,8 \\
\hline & Female & 213 & 53,3 \\
\hline \multicolumn{4}{|l|}{ Age } \\
\hline & $19-25$ & 64 & 16,0 \\
\hline & $26-30$ & 115 & 28,8 \\
\hline & $31-35$ & 70 & 17,5 \\
\hline & $36-40$ & 57 & 14,3 \\
\hline & $41-45$ & 40 & 10,0 \\
\hline & $46-50$ & 21 & 5,3 \\
\hline & $51-73$ & 33 & 8,3 \\
\hline \multicolumn{4}{|l|}{ Marital Status } \\
\hline & Single & 169 & 42,3 \\
\hline & Married & 231 & 57,8 \\
\hline \multicolumn{4}{|l|}{ Education Level } \\
\hline & Primary & 23 & 5,8 \\
\hline & Secondary & 118 & 29,5 \\
\hline & University, Postgraduate & 259 & 64,8 \\
\hline \multicolumn{4}{|l|}{ Occupation } \\
\hline & Doesn't work & 20 & 5,0 \\
\hline & Retired & 22 & 5,5 \\
\hline & Working & 358 & 89,5 \\
\hline \multicolumn{4}{|l|}{ Working Place } \\
\hline & White Collar & 222 & 55,5 \\
\hline & Blue Collar & 99 & 24,8 \\
\hline & Entrepreneur & 39 & 9,8 \\
\hline \multicolumn{4}{|l|}{ Car Ownership } \\
\hline & No & 190 & 47,5 \\
\hline & Yes & 210 & 52,5 \\
\hline \multicolumn{4}{|l|}{ Monthly Income } \\
\hline & Less than1500 TL & 95 & 23,8 \\
\hline & 1500-3000 TL & 158 & 39,5 \\
\hline & $3001-4500 \mathrm{TL}$ & 95 & 23,8 \\
\hline & 4500 TL or more & 52 & 13,0 \\
\hline
\end{tabular}


As it is seen in Table 2, the most preferred brand by consumers is Ford. The Peugeot brand, which is main concern in this survey, has been preferred by only 17 of the car-owners among the participants. Considering that Peugeot and Citroën are brands of the same group, a total of 36 people chose the two brands. When French car brands Peugeot, Citroën and Renault are considered, it is observed that 53 participants have chosen the French car brands.

Table 2: Participants' Car Brands and Country of Origin

\begin{tabular}{|c|c|c|c|c|c|}
\hline Country of Origin & Brand & Frequency & Percentage & General Frequency & General Percentage \\
\hline \multirow[b]{4}{*}{ USA } & Ford & 35 & 16,43 & \multirow{4}{*}{38} & \multirow{4}{*}{17,8} \\
\hline & Cherokee Jeep & 1 & 0,47 & & \\
\hline & Chevrolet & 1 & 0,47 & & \\
\hline & Chrysler & 1 & 0,47 & & \\
\hline \multirow[b]{3}{*}{ France } & Citroën & 17 & 8 & \multirow[t]{3}{*}{53} & \multirow[t]{3}{*}{25} \\
\hline & Renault & 17 & 8 & & \\
\hline & Peugeot & 19 & 9 & & \\
\hline \multirow[b]{6}{*}{ Germany } & Volkswagen & 18 & 8,4 & \multirow[t]{6}{*}{52} & \multirow[t]{6}{*}{24} \\
\hline & Opel & 16 & 7,5 & & \\
\hline & BMW & 7 & 3,3 & & \\
\hline & Audi & 4 & 1,8 & & \\
\hline & Mercedes & 4 & 1,8 & & \\
\hline & Skoda & 3 & 1,4 & & \\
\hline \multirow[b]{3}{*}{ Italy } & Fiat & 19 & 9 & \multirow[t]{3}{*}{22} & \multirow[t]{3}{*}{10} \\
\hline & Alfa Romeo & 1 & 0,47 & & \\
\hline & Tofaş & 2 & 0,9 & & \\
\hline \multirow[b]{5}{*}{ Japan } & Honda & 14 & 6,5 & \multirow[t]{5}{*}{27} & \multirow[t]{5}{*}{12,5} \\
\hline & Toyota & 7 & 3,3 & & \\
\hline & Nissan & 3 & 1,4 & & \\
\hline & Mazda & 2 & 0,9 & & \\
\hline & Daihatsu & 1 & 0,47 & & \\
\hline \multirow[b]{2}{*}{ South Korea } & Hyundai & 10 & 4,7 & \multirow[t]{2}{*}{14} & \multirow[t]{2}{*}{6,5} \\
\hline & Kia & 4 & 1,8 & & \\
\hline Spain & Seat & 6 & 2,9 & 6 & 4,7 \\
\hline India & Tata & 1 & 0,47 & 1 & 0,47 \\
\hline
\end{tabular}

\subsection{Measurement Analysis}

Firstly, for the validity of scales in terms of structure Exploratory Factor Analysis was conducted. Once it is determined that the data set is suitable for factor analysis (Creation of correlation matrix, Barlett test and Kaiser-Meyer-Olkin (KMO) tests) (Kalaycl, 2006; Büyüköztürk, 2012) and as a result of factor analysis of the Promax Rotation key components on the data set, 5 factors above the value of 1 are determined. The brand image is divided into two factors in itself. According to Koubaa (2008), brand image is a multi-dimensional structure and brand image structures may differ according to brands and origin countries. In this study, the image of Peugeot brand has come out in two dimensions. The five factors included in the research model, their statistical values and factor analysis results are shown in the table 3 below. 
Table 3: Factors and Values

\begin{tabular}{|l|l|c|c|c|c|c|c|c|}
\hline \multicolumn{2}{|c|}{ Factors } & Mean & $\begin{array}{c}\text { Std. } \\
\text { Dev. }\end{array}$ & $\begin{array}{c}\text { Cronbach's } \\
\text { Alpha }\end{array}$ & $\begin{array}{c}\text { Variance } \\
\text { Exp. }\end{array}$ & KMO & $\begin{array}{c}\text { Chi- } \\
\text { square }\end{array}$ & $\begin{array}{c}\text { Sig. } \\
\text { p }\end{array}$ \\
\hline \multirow{2}{*}{$\begin{array}{l}\text { Peugeot } \\
\text { Brand Image }\end{array}$} & Quality and Style & 3,036 & 0,978 & 0,91 & 49,95 & 0,917 & 2480,53 & 0,001 \\
\cline { 2 - 8 } & Market Place & 3,527 & 0,893 & 0,66 & 11,41 & 0,917 & 2480,53 & 0,001 \\
\hline France Image & 3,463 & 0,98 & 0,67 & 59 & 0,619 & 187,97 & 0,001 \\
\hline General Image of French Products & 2,866 & 1,04 & 0,91 & 73,80 & 0,877 & 1341,89 & 0,001 \\
\hline Ethnocentrism & 3,079 & 1,246 & 0,94 & 63,98 & 0,946 & 4952,71 & 0,001 \\
\hline
\end{tabular}

Another process for the validity of the structure was the Confirmatory Factor Analysis (CFA) in AMOS. Since the load values of the expressions in the DFA analysis are expected to be close to 0.60 (Kline, 2005, p.178), the items with low load values (s9, s48, s16, s62) were recycled one by one. As a result the following values obtained were supported by the literature (Cole, 1987; Kline, 2005; Uğurlu, 2014; Meydan and Şeşen, 2015).

Table 4: CFA Compliance Values

\begin{tabular}{lll}
\hline Indices & Acceptable fit & Value \\
\hline Cmin/DF & $\chi^{2} \leq 3$ & 2,561 \\
CFI & $0,90 \leq \mathrm{CFI} \leq 0,97$ & 0,913 \\
$\mathrm{NFI}$ & $0,80 \leq \mathrm{NFI} \leq 0,95$ & 0,865 \\
$\mathrm{GFI}$ & $0,80 \leq \mathrm{GFI} \leq 0,95$ & 0,828 \\
SRMR & $0,08 \geq \mathrm{SRMR} \geq 0,05$ & 0,052 \\
Rmsea & $0,08 \geq \mathrm{Rmsea} \geq 0,05$ & 0,063 \\
\hline
\end{tabular}

As a result of the Confirmatory Factor Analysis, the path was continued with an acceptable structure of 5 factors and 33 expressions.

\subsection{Tests of Hypotheses}

Hypotheses were constructed with AMOS in Structural Equation Modeling. As a result of the analysis made on data collected from a total of 400 respondents, the compliance values of the model are found as follows: $\chi 2 / \mathrm{df}=2,743, \mathrm{CFI}=0,902, \mathrm{NFI}=0,855, \mathrm{GFI}=$ $0,820, \mathrm{SRMR}=0,065, \mathrm{RMSEA}=0,066$. According to Kline (2005), RMSEA, SRMR, CFI, NFI and Cmin / DF ratios must be at an acceptable level. NFI and GFI have relatively low compliance values, although they are acceptable. $\mathrm{H} 1, \mathrm{H} 4, \mathrm{H} 5 \mathrm{~b}, \mathrm{H} 6 \mathrm{a}, \mathrm{H} 6 \mathrm{~b}$ were supported according to the findings in the hypotheses analysis results; $\mathrm{H} 2, \mathrm{H} 3 \mathrm{a}, \mathrm{H} 3 \mathrm{~b}$ and $\mathrm{H} 5 \mathrm{a}$ were not supported. Especially $\mathrm{H} 3 \mathrm{a}$ and $\mathrm{H} 3 \mathrm{~b}$, although statistically significant, do not meet the negative expectations of the hypotheses and do not support the hypotheses because they have a positive effect. Moreover, although it was not hypothesized in the research, it was also found that the image of France and France's general product image were also examined but not mediated.

Table 5: Tests of Hypothesis

\begin{tabular}{lcccc}
\hline Structural path & Estimates & S.E. & P & $\begin{array}{l}\text { Hypotheses } \\
\text { Results }\end{array}$ \\
\hline H1.Ethnocentrism $\rightarrow$ France image & $-0,19$ & 0,05 & $* * *$ & Supported \\
H2. Ethnocentrism $\rightarrow$ General image of French products & 0,02 & 0,04 & 0,58 & Not supported \\
H3a. Ethnocentrism $\rightarrow$ The Quality and Style of Peugeot Brand & 0,09 & 0,02 & $* * *$ & Not supported \\
H3b. Ethnocentrism $\rightarrow$ The Market Place of Peugeot Brand & 0,07 & 0,03 & 0,03 & Not supported \\
H4. France image $\rightarrow$ General image of French products & 0,40 & 0,07 & $* * *$ & Supported \\
H5a. France image $\rightarrow$ The Quality and Style of Peugeot Brand & 0,03 & 0,04 & 0,43 & Not supported \\
H5b. France image $\rightarrow$ The Market Place of Peugeot Brand & 0,27 & 0,06 & $* * *$ & Supported \\
H6a. General image of French products $\rightarrow$ The Quality and Style of & 0,38 & 0,04 & $* * *$ & Supported
\end{tabular}




\section{CONCLUSION}

The aim of this research was to determine how the ethnocentric tendencies of individuals trained in Turkish culture affect the image of a foreign country and its products. For this purpose, research has been carried out on the Peugeot brand of France origin, which is one of the best-selling automobile brands in Turkey (for more details, Appendix 1). The appropriate scales in the literature have been determined for the study and the validity and reliability of these scales have been tested. Once the validity and reliability of these scales were determined and found to be acceptable, hypotheses testing was undertaken. Hypotheses were tested with AMOS and the following results were obtained. The ethnocentric tendency of Turkish consumers on France, French products and Peugeot brand image has been tested with the hypotheses $\mathrm{H} 1, \mathrm{H} 2, \mathrm{H} 3 \mathrm{a}$ and $\mathrm{H} 3 \mathrm{~b}$. As a result, $\mathrm{H} 1(\beta=-.19, \mathrm{p}<0.05)$ was supported and $\mathrm{H} 2(\beta=.02, \mathrm{p}>0.05)$ was not supported. In addition, $\mathrm{H} 3 \mathrm{a}(\beta=.09, \mathrm{p}<0.05)$ and $\mathrm{H} 3 \mathrm{~b}(\beta=.07, \mathrm{p}<0.05)$ were found to be positive instead of negative and statistically significant. Therefore even though $\mathrm{H} 3 \mathrm{a}$ and $\mathrm{H} 3 \mathrm{~b}$ found to be significant statistically they do not support hypotheses because they do not have a negative effect. According to He and Wang (2014), the negative effect of consumer ethnocentrism decreases when the value and prestige of imported brand is high. Like the fact that the Peugeot brand is not affected negatively by the ethnocentric tendencies of Turkish consumers, it's estimated that could be a reflection of its brand value. It is known that the perceived quality of the brand reduces the negative effect of ethnocentrism (Elliott and Cameron, 1994). It can be a sign why it is one of the most preferred automobile brands, especially in Turkey. Also the fact that Turkey does not produce its own automobiles, it could also affect this situation. According to research by Kaynak and Kara (2000) on Turkish consumers, Turkish consumers have a very positive perception of products from Japan, USA and Western European countries. The fact that the Peugeot brand belongs to France, one of the western European countries, is likely to have produced such a result. Therefore, according to the results of this research, consumer ethnocentrism generally affects the country image in general and France image negatively in particular. On the contrary, consumer ethnocentrism has a positive and significant effect on the Peugeot image, a French brand, instead of a negative. According to the result of the research ethnocentric barriers may point to France but it is not toward to Peugout auto brand. One of the probabilities of these results is that most of the activities that Porter (1985) mentioned in the value chain model carried out in Turkey. In other words, some French cars manufacturing in Turkey is an indicator for value sharing. Through value sharing, while the business could make profit economically they also socially benefits to the country and the community. According to findings, ethnocentrism has no significant effect on the overall image of French products.

The effect of the image of France as a country of origin on general products and on the brand has been tested with $\mathrm{H} 4$, $\mathrm{H} 5 \mathrm{a}$ and $\mathrm{H} 5 \mathrm{~b}$. $\mathrm{H} 4 \mathrm{a}(\beta=.40, \mathrm{p}<0.05)$ and $\mathrm{H} 5 \mathrm{~b}(\beta=.03, \mathrm{p}<0.05)$ were supported, while $\mathrm{H} 5 \mathrm{a}(\beta=.03, \mathrm{p}>0.05)$ was not statistically significant. The results (Schooler, 1965; Nagashima, 1970; Roth and Romeo, 1992; Parameswaran and Pisharodi, 1994; Lee and Ganesh, 1999; Huddleston et al., 2001; Dinnie, 2003; Felzensztein and Dinnie, 2005; Lin and Chen, 2006; Koubaa, 2008; Roth and Diamantopoulos, 2009) are also parallel to the literature. So, in accordance to that, the image of France as the image of the country of origin affects the general image of French products and the image of the market position of its own brand Peugeot positively and meaningfully; it does not affect the image of the Peugeot brand's product statistically.

The effect on the brand image of the country's general product image was tested with $\mathrm{H} 6 \mathrm{a}$ and H6b. According to the results, $\mathrm{H} 6 \mathrm{a}$ $(\beta=.38, p<0.05)$ and $\mathrm{H} 6 \mathrm{~b}(\beta=.18, p<0.05)$ both hypotheses have a meaningful and positive effect. Accordingly, the general image of French products affects positively and significantly both Peugeot's quality and style image and Peugeot's market position image. Considering that Turkish consumers have a positive attitude towards Western European products (Kaynak and Kara, 2000), we can see that this positive attitude is also reflected in the Peugeot brand, a brand belonging to this region. This is also known as halo effect in the literature (Han, 1989; Han, 1990; Lampert and Jaffe, 1998). Therefore, it is possible to say that the general product image belonging to France has a halo effect on the brand image.

\subsection{Managerial Implications}

Ethnocentrism for international firms is an important variable that needs to be tackled. Most of the consumers don't want to buy imported products, instead they prefer to choose their own products. In this respect, they are more likely to prefer local products and brands by exhibiting a negative attitude towards imported products and brands. Automobile brands were also facing such a situation in the international market. But in developing countries like Turkey, the situation can be different. Because of the absence of the domestic automobile brand in countries that do not produce their own automobiles creates an opportunity for 
imported brands. The findings of this research show that an imported brand such as Peugeot is not much affected by consumer ethnocentrism in Turkey. It is estimated that this is due to both the lack of the domestic automobile brand and the other features of the brand. Therefore, automobiles with high quality and prestige perception have a high chance of success in markets such as Turkey without being significantly affected by ethnocentrism.

According to the results of the survey, the Peugeot brand was also influenced by the general product image of the country and country of origin. In order to be preferred by more consumers and to have a larger market share, it may be positive for the brand to carry out their work in such a way that Peugeot marketing team takes into account the country image, the general product image of the country and the effects of ethnocentrism. Research similar to this can be useful for the target markets of Peugeot Brand. It will be useful to brand to carry out such researches in markets that are already in existence to assist in correct positioning. This type of research which shows how consumers perceive Peugeot and France, also contributes to the future plans of the brand.

\section{Acknowledgment}

This article is the developed version of the conference paper, whose information is given below.

Conference paper: "Which is the moderator of ethnocentrism: Country or product image?".

\section{REFERENCES}

Aaker, D. A. (1991). Managing brand equity - capitalizing on the value of a brand name. New York: The Free Press.

Ahmed, Z. U., Johnson, J. P., Pei Ling, C., Wai Fang, T., \& Kah Hui, A. (2002). Country-of-origin and brand effects on consumers' evaluations of cruise lines.International Marketing Review, 19(3), 279-302.

Akkaya, E. (1999). Marka imajı ve bileşenleri: otomobil sektöründe bir uygulama. 4. Ulusal Pazarlama Kongresi (s. 101-111). Antakya-Hatay: Mustafa Kemal Üniversitesi.

Al-Sulaiti, K., \& Baker, M. (1998). Country of origin effects: a literature review. Marketing Intelligence \& Planning, 16, s. $150-199$.

Asil, H., \& Kaya, İ. (2013). Türk tüketicilerin etnosentrik eğilimlerinin belirlenmesi üzerine bir araştırma. İstanbul Üniversitesi İşletme Fakültesi Dergisi, 42, s. 113-132.

Barich, H., \& Kotler, P. (1991). A framework for marketing image management. Sloan Management Review (94), 94-104.

Bilkey, W., \& Nes, E. (1982). Country of origin effects on product evaluations. Journal of International Business Studies, (Spring/Summer) s. 89-99.

Bilkey, W., \& Nes, E. (1982). Country of origin effects on product evaluations. Journal of International Business Studies, (Spring/Summer) s. 89-99.

Bruning, E. (1997). Country of origin, national loyalty and product choice: the case of international air travel. International Marketing Review, 14, S. 59-74.

Büyüköztürk, Ş. (2012). Sosyal Bilimler İçin Veri Analizi El Kitabı (16. baskı). Ankara: Pegem Akademi.

Cole, D.A. (1987). Utility of confirmatory factor analysis in test validation research. Journal of Consulting and Clinical Psychology, 55, $1019-1031$.

Darren, G., \& Mallery, P. (2003). SPSS for Windows Step by Step: A Simple Guide and Reference 11.0 update. Boston: Allyn and Bacon.

Diamantopoulos, A., Schlegelmilch, B., \& Palihawadana, D. (2011). The relationship between country-of-origin image and brand image as drivers of purchase intentions: a test of alternative perspectives. International Marketing Review, 28(5), 508-524.

Dinnie, K. (2003). Country of origin 1965-2004: a literature review. Journal of Consumer Behavior.

Dobni, D., \& Zinkhan, G. M. (1990). In search of brand image: a foundation analysis. Advances in Consumer Research, s. $110-119$.

Elliott, G. R., \& Cameron, R. C. (1994). Consumer perception of product quality and the country-of-origin effect. Journal of international Marketing, 49-62.

Eng, T. Y., Ozdemir, S., \& Michelson, G. (2016). Brand origin and country of production congruity: Evidence from the UK and China. Journal of Business Research, 69(12), 5703-5711.

Erdoğan, B.Z., \& Uzkurt, C. (2010). Effects of ethnocentric tendecy on consumers' perception of product attitudes for foreign and domestic products. Cross Cultural Management: An International Journal, 17, s. 393-406.

Essoussi, L., \& Merunka, D. (2007). Consumers' product evaluations in emerging markets: does country of design, country of manufacture, or brand image matter? International Marketing Review, 24(4), 409-426. 
Fakharmanesh, S., \& Miyandehi, R. G. (2013). The purchase of foreign products: The role of brand image, ethnocentrism and animosity: Iran market evidence. Iranian Journal of Management Studies, 6(1), 147.

Felzensztein, C., \& Dinnie, K. (2006). The effects of country of origin on UK consumers' perceptions of imported wines. Journal of Food Products Marketing, 11(4), 109-117.

Good, L. K., \& Huddleston, P. (1995). Ethnocentrism of Polish and Russian consumers: are feelings and intentions related. International Marketing Review, 12(5), 35-48.

Han, M. (1989). Country image: halo or summary construct. Journal of Marketing Research, 26, s. 222-229.

Han, M. (1990). Testing the role of country image in consumer choice behaviour. European Journal of Marketing, 24, s. 24-40.

He, J., \& Wang, C. L. (2015). Cultural identity and consumer ethnocentrism impacts on preference and purchase of domestic versus import brands: An empirical study in China. Journal of Business Research, 68(6), 1225-1233.

Herche, J. (1994). Ethnocentric tendencies, marketing strategy and import purchase behaviour. International Marketing Review, 11 , s. 4-16.

Herche, J. (1994). Ethnocentric tendencies, marketing strategy and import purchase behaviour. International Marketing Review, 11 , s. 4-16.

Heslop, L. A., \& Papadopoulos, N. (1993). But who knows where or when: Reflections on the images of countries and their products. Productcountry images: Impact and role in international marketing, 39-75.

Hinner, M. (2010). Stereotyping and the country-of-origin effect. China Media Research, 6, s. 47-57.

Huddleston, P., Good, L. K., \& Stoel, L. (2001). Consumer ethnocentrism, product necessity and Polish consumers' perceptions of quality. International Journal of Retail \& Distribution Management, 29 (5), s. 236-246.

Insch, A., Williams, S., \& Knight, J. G. (2015). Managerial perceptions of country-of-origin: an emprical study of New Zealand food manufacturers. Journal of Food Products Marketing, s. 1-17.

Johansson, J. K. (1989). Determinants and effects of the use of "made in" labels. International Marketing Review, 6, s. 47-58.

Kalaycı, Ş. (2006). SPSS Uygulamalı Çok Değişkenli İstatistik Teknikleri (2. baskı). Ankara: Asil Yayın.

Kapferer, J. N. (2008). The new strategic brand management. London; Philadelphia: Kogan Page.

Kaynak, E. and Kara, A. (2002), “Consumer perceptions of foreign products”, European Journal ofMarketing, Vol. 36 Nos 7/8, pp. 928-949.

Kinra, N. (2006). The effect of country-of-origin on foreign brand names in the Indian market. Marketing Intelligence \& Planning, 24(1), 15-30.

Kline, R. B. (2005). Principles and practice of structural equation modeling (2. baskı). New York: The Guilford Press.

Kotler, P. H. (1991). Marketing management: analysis, planning and control (8. Baskı b.). Englewood Cliffs: NJ: Prentice-Hall, Inc.

Koubaa, Y. (2008). Country of origin, brand image perception, and brand image structure. Asia Pacific Journal of Marketing and Logistics, 20(2), 139-155.

Lampert, S. I., \& Jaffe, E. D. (1998). A dynamic approach to country-of-origin effect. European Journal of Marketing, 32 (1/2), s. 61-78.

Lee, D., \& Ganesh, G. (1999). Effects of partitioned country image in the context of brand image and familiarity: A categorization theory perspective. International Marketing Review, 16(1), 18-41.

Lin, L. Y., \& Chen, C. S. (2006). The influence of the country-of-origin image, product knowledge and product involvement on consumer purchase decisions: an empirical study of insurance and catering services in Taiwan. Journal of consumer Marketing, 23(5), 248-265.

Lu Wang, C., \& Xiong Chen, Z. (2004). Consumer ethnocentrism and willingness to buy domestic products in a developing country setting: testing moderating effects. Journal of Consumer Marketing, 21(6), 391-400.

Maher, A. A., \& Carter, L. L. (2011). The affective and cognitive components of country image: Perceptions of American products in Kuwait. International Marketing Review, 28(6), 559-580.

Maronick, T. J. (1995). An emprical investigation of consumer perceptions of "Made in USA" claims. International Marketing Review, 12 , s.15-31.

Martin, I. M., \& Eroglu, S. (1993). Measuring a multi-dimensional construct: country image. Journal of business research, $28(3), 191-210$.

Martinez, T. L., Ibanez, J. A., \& Garcia, S. d. (2000). Consumer ethnocentrism measurement- An assessment of the reliability and validity of the CETSCALE in Spain. European Journal of Marketing, 34 (11/12), s. 1353-1374.

Meydan, C. H. \& Şeşen, H., 2015. Yapısal eşitlik modellemesi AMOS uygulamaları. 2. dü. Ankara: Detay Yayıncılık. 
Moon, B. J., \& Jain, S. C. (2002). Consumer processing of foreign advertisements: roles of country-of-origin perceptions, consumer ethnocentrism, and country attitude. International Business Review, 11(2), 117-138.

Morello, G. (1983). The 'made in' issue a comparative research on the image of domestic and foreign products. Researchmemorandum, 18.

Nagashima, A. (1970). A comparison of Japaneseand US attitudestowardforeignproducts. TheJournal of Marketing, 68-74.

Nagashima, A. (1977). A comparative "made in" product image survey among Japanese businessmen. Journal of Marketing, 41, s. 95-100.

Nebenzahl, I. D.,Jaffe, E. D., \&Lampert, S. I. (1997). Towards a theory of country image effect on product evaluation. MIR: Management International Review, 27-49.

Özçelik, D. G., \& Torlak, Ö. (2011). Marka kişiliği algısı ile etnosentrik eğilimler arasındaki ilişki: LEVIS ve MAVi JEANS üzerine bir uygulama. Ege Akademik Bakış, 11(3), s. 361-377.

Parameswaran, R., \& Pisharodi, R. M. (1994). Facets of country of origin image: an empirical assessment. Journal of advertising, 23(1), 43-56.

Peterson, R. A., \& Jolibert, A. J. (1995). A meta-analysis of country-of-origin effects. Journal of International Business Studies, 26, s.883-896

Reierson, C. (1966). Are foreign products seen as national stereotypes? a survey of attitudes in college students. Journal of Retailing, s. 33-40.

Roth, K. P., \& Diamantopoulos, A. (2009). Advancing the country image construct. Journal of Business Research, 62(7), 726-740.

Roth, M. S., \& Romeo, J. B. (1992). Matching product catgeory and country image perceptions: A framework for managing country-of-origin effects. Journal of international business studies, 23(3), 477-497.

Schooler, R. D. (1965). Product bias in the Central American common market.Journal of Marketing Research, 394-397.

Sharma, S., Shimp, T. A., \& Shin, J. (1995). Consumer ethnocentrism: A test of antecedents and moderators. Journal of the academy of marketing science, 23(1), 26-37.

Shimp, T. (1984). Consumer ethnocentrism: the concept and a preliminary empirical test. Advances in Consumer Research, 11, s. 285-290.

Shimp, T. A., \& Sharma, S. (1987, Ağustos). Consumer ethnosentrism: construction and validation of the CETSCALE. Journal of Marketing Research, 24, s. 280-289.

Suh, Y., Hur, J., \& Davies, G. (2016). Cultural appropriation and the country of origin effect. Journal of Business Research, 69(8), 2721-2730.

Tabachnick, B. G., \& Fidell, L. S. (2011). Using Multivariate Statistics (6. baskı). Boston: Pearson.

Thomas, M., \& Hill, H. (1999). The impact of ethnocentrism on devising and implementing a corporate identity strategy for new international markets. International Marketing Review, 16(4/5), 376-390.

Tse, D. K., \& Lee, W. N. (1993). Removing negative country images: Effects of decomposition, branding, and product experience. Journal of International Marketing, 25-48.

Uğurlu, C. T. (2014). İnformal iletişim ölçeği geçerlik ve güvenirlik çalışması. İnönü Üniversitesi Eğitim Fakültesi Dergisi, 15(3).

Usunier, J.-C. (1996). Marketing across cultures (2. baskı). Hertfordshire: Prentice Hall Europe.

Wang, C.-K., \& Lamb, C. W. (1983). The impact of selected environmental forces upon consumers' willingness to buy foreign products. Journal of Marketing Science, 11, s. 71-84.

Watson, J. J., \& Wright, K. (2000). Consumer ethnocentrism and attitudes toward domestic and foreign products. European journal of Marketing, 34(9/10), 1149-1166.

http://www.odd.org.tr/web_2837_2/neuralnetwork.aspx?type=36 (28.03.2021) 
APPENDIX 1

\begin{tabular}{|c|c|c|c|c|}
\hline \multicolumn{5}{|c|}{ Passenger car and light commercial vehicle market in Turkey } \\
\hline \multirow[t]{2}{*}{ Brand Name } & \multicolumn{3}{|c|}{ Years } & \multirow[b]{2}{*}{ Total } \\
\hline & 2018 & 2019 & 2020 & \\
\hline ALFA ROMEO & 203 & 253 & 214 & 670 \\
\hline ASTON MARTIN & 16 & 18 & 17 & 51 \\
\hline AUDI & 13.295 & 10.024 & 18.168 & 41.487 \\
\hline BENTLEY & 10 & 9 & 11 & 30 \\
\hline BMW & 12.728 & 9.583 & 14.270 & 36.581 \\
\hline CITROEN & 12.302 & 12.033 & 27.480 & 51.815 \\
\hline DACIA & 29.918 & 20.006 & 30.800 & 80.724 \\
\hline DS & 236 & 269 & 694 & 1.199 \\
\hline FERRARI & 18 & 20 & 21 & 59 \\
\hline FIAT & 70.058 & 76.251 & 137.325 & 283.634 \\
\hline FORD & 65.428 & 47.107 & 92.487 & 205.022 \\
\hline HONDA & 28.661 & 20.354 & 22.222 & 71.237 \\
\hline HYUNDAI & 33.502 & 23.900 & 28.531 & 85.933 \\
\hline INFINITI & 18 & 0 & 0 & 18 \\
\hline ISUZU & 2.238 & 925 & 545 & 3.708 \\
\hline IVECO & 1.598 & 1.326 & 1.851 & 4.775 \\
\hline JAGUAR & 220 & 244 & 265 & 729 \\
\hline JEEP & 2.430 & 2.123 & 4.369 & 8.922 \\
\hline KARSAN & 960 & 511 & 404 & 1.875 \\
\hline KIA & 9.641 & 6.342 & 15.442 & 31.425 \\
\hline LAMBORGHINI & 3 & 9 & 19 & 31 \\
\hline LAND ROVER & 1.248 & 1.371 & 2.010 & 4.629 \\
\hline LEXUS & 56 & 85 & 143 & 284 \\
\hline MASERATI & 55 & 45 & 47 & 147 \\
\hline MAZDA & 1.005 & 417 & 156 & 1.578 \\
\hline MERCEDES-BENZ & 22.438 & 14.936 & 20.792 & 58.166 \\
\hline MINI & 1.373 & 1.254 & 1.395 & 4.022 \\
\hline MITSUBISHI & 4.159 & 2.627 & 5.866 & 12.652 \\
\hline NISSAN & 26.346 & 13.067 & 13.261 & 52.674 \\
\hline OPEL & 20.960 & 18.059 & 34.296 & 73.315 \\
\hline PEUGEOT & 30.152 & 28.861 & 43.674 & 102.687 \\
\hline PORSCHE & 565 & 361 & 619 & 1.545 \\
\hline RENAULT & 85.839 & 64.977 & 101.534 & 252.350 \\
\hline SEAT & 10.383 & 5.914 & 11.551 & 27.848 \\
\hline SKODA & 21.340 & 15.369 & 24.175 & 60.884 \\
\hline
\end{tabular}




\begin{tabular}{|l|c|c|c|c|}
\hline SMART & 35 & 44 & 49 & 128 \\
\hline SSANGYONG & 396 & 371 & 1.084 & 1.851 \\
\hline SUBARU & 1.471 & 662 & 673 & 2.806 \\
\hline SUZUKI & 2.878 & 2.381 & 2.977 & 8.236 \\
\hline TOYOTA & 33.978 & 24.301 & 40.375 & 98.654 \\
\hline VOLKSWAGEN & 66.834 & 48.496 & 64.776 & 180.106 \\
\hline VOLVO & 5.943 & 4.155 & 8.200 & 18.298 \\
\hline Total & $\mathbf{6 2 0 . 9 3 7}$ & $\mathbf{4 7 9 . 0 6 0}$ & $\mathbf{7 7 2 . 7 8 8}$ & $\mathbf{1 . 8 7 2 . 7 8 5}$ \\
\hline
\end{tabular}

http://www.odd.org.tr/web_2837_2/neuralnetwork.aspx?type=36 